\title{
Heart Valve Tissue
}

National Cancer Institute

\section{Source}

National Cancer Institute. Heart Valve Tissue. NCI Thesaurus. Code C133338.

Tissue derived from the heart valves that allow blood flow through the heart. 